\title{
Pengaruh Subtitusi Tepung Mocaf (Modified Cassava Flour) terhadap Sifat Fisik dan Sensoris Bolu Kukus
}

\author{
Effect of Mocaf (Modified Cassava Flour) Substitution on Phisical and Sensory \\ Properties of Steamed Sponge Cake \\ Khusnul Khotimah*, Akbar, Anis Syauqi, Ahmad Zamroni \\ Program Studi Teknologi Hasil Perkebunan, Politeknik Pertanian Negeri Samarinda, \\ Samarinda, Indonesia. \\ ${ }^{*}$ Correspondence Author: khusnulnew17@gmail.com
}

\begin{abstract}
ABSTRAK
Ketersediaan tepung mocaf sebagai hasil fermentasi dari tepung singkong dapat dimanfaatkan sebagai bahan subtitusi dalam pembuatan produk olahan pangan. Penelitian ini dilakukan untuk mengetahui pengaruh subtitusi tepung mocaf sebagai bahan pengganti tepung terigu dalam pembuatan bolu kukus terhadap tingkat kesukaan konsumen dan daya pengembangan bolu kukus yang dihasilkan. Pada penelitian ini, mocaf digunakan dalam pembuatan bolu kukus dengan variasi perbandingan terhadap tepung terigu (\%) sebagai berikut: $0: 100,10: 90,20: 80,30: 70$, dan 40:60. Hasil penelitian menunjukkan bahwa bolu kukus yang dihasilkan memiliki nilai uji sensoris yang tidak berbeda nyata pada semua tingkat perlakuan. Rata-rata panelis memberikan nilai "agak suka" terhadap rasa, aroma, tekstur dan warna bolu kukus yang dihasilkan. Rata-rata nilai daya pengembangan berkisar antara $110 \%$ sampai dengan $125 \%$. Tidak ada perbedaan yang nyata antara nilai daya pengembangan bolu kukus yang terbuat dari tepung mocaf dengan bolu kukus berbahan tepung terigu $100 \%$. Hal ini menunjukkan bahwa mocaf dapat dijadikan sebagai bahan pengganti tepung terigu dalam pembuatan bolu kukus dengan kualitas produk akhir yang relatif sama dengan bolu kukus berbahan dasar tepung terigu.
\end{abstract}

Kata Kunci: Tepung Mocaf, Bolu Kukus, Uji Sensoris

\begin{abstract}
The availability of mocaf flour as a result of fermentation from cassava flour can be used as a substitute material in the manufacture of processed food products. This research was conducted to determine the effect of mocaf flour substitution as a substitute for wheat flour in the manufacture of steamed sponge to the level of consumer preferences and the development power of steamed sponge produced. In this study, mocaf was used in making steamed sponge with various ratio of wheat flour (\%) as follows: 0: 100, 10:90, 20:80, 30:70, and 40:60. The results showed that the resulting steamed cake had sensory test values that were not significantly different at all treatment levels. The average panelist gave a "rather like" value to the taste, aroma, texture and color of the resulting steamed sponge. The average value of development power ranges from $110 \%$ to $125 \%$. There is no significant difference between the value of the development power of steamed sponge made from mocaf flour and steamed sponge made from 100\% flour. This shows that mocaf can be used as a substitute for wheat flour in steamed sponge cake production with the same final product quality as wheat flour-based steamed sponge.

Keywords: Mocaf Flour, Steamed Sponge Cake, Sensory Test
\end{abstract}

\section{PENDAHULUAN}

Seiring dengan pertumbuhan jumlah penduduk, konsumsi tepung terigu di Indonesia dari tahun ke tahun semakin meningkat. Badan Pusat Statistik (2011) melaporkan bahwa konsumsi terigu di Indonesia pada tahun 2010 mencapai 4,3 juta ton dan meningkat menjadi 4,6 juta ton pada tahun 2011. Peningkatan konsumsi tepung terigu dalam beberapa kurun waktu terakhir ini juga dipicu oleh semakin meningkatnya industri kecil menengah (UKM) yang mengolah produk berbasis terigu (Ruriani dkk., 2013). Kondisi ini menempatkan Indonesia sebagai negara 
pengimpor gandum terbesar kedua di dunia (Central Data Mediatama Indonesia, 2013). Ketergantungan yang tinggi terhadap gandum perlu dikurangi secara bertahap karena dapat mengancam ketahanan pangan nasional. Oleh karena itu, Indonesia memerlukan bahan pengganti tepung terigu yang bisa diproduksi dengan menggunakan bahan baku lokal. Salah satu bahan alternatif yang dapat dijadikan pengganti tepung terigu adalah tepung MOCAF (modified cassava flour) yang berbahan dasar singkong.

MOCAF adalah produk tepung singkong yang diproses menggunakan prinsip memodifikasi sel singkong dengan fermentasi dimana mikroba BAL (Bakteri Asam Laktat) adalah mikroba yang mendominasi selama fermentasi tepung singkong (Diniyah dkk., 2018). MOCAF dapat dibuat dari singkong varietas manis (sweet cassava) maupun varietas pahit (bitter cassava). MOCAF dari singkong manis baik untuk pembuatan kue dan biskuit, karena cita rasa singkong yang tidak terlalu kuat, sedangkan MOCAF dari varietas pahit juga bisa, tapi hasilnya tidak sebaik yang $\mathrm{HCN}$-nya rendah (Subagio dkk., 2008).

Penggunaan mocaf sebagai bahan pangan cukup luas dan fleksibel karena dapat dicapur/dikomposit dengan tepungtepungan lainya baik terigu, beras, ketan maupun kacang-kacangan. Proporsi mocaf sebagai bahan subtitusi terigu bervariasi antara $30-40 \%$ pada produk roti, pastry dan mie, $50-100 \%$ pada produk kue basah (cakes), kue kering (Cookies), aneka produk gorengan dan jajanan basah/pasar (Yulifianti dkk, 2012).

Bolu kukus merupakan produk yang dihasilkan dari tepung terigu atau jenis tepung lain dengan penambahan bahanbahan lain yang diproses dengan pengukusan atau pengovenan. Kualitas kue bolu kukus ditentukan dari rasa, tekstur, aroma dan tingkat pengembangan (Hapsari 2015). Subtitusi tepung terigu dengan tepung mocaf untuk pembuatan produk-produk olahan dapat memberikan manfaat yaitu mengurangi ketergantungan terhadap impor gandum. Akan tetapi, subtitusi tepung terigu dengan mocaf tentu perlu mempertimbangkan proporsi yang tepat agar dapat diperoleh produk akhir yang berkualitas sama atau bahkan lebih baik dari pada produk yang dibuat dengan tepung terigu. Oleh karena itu, penelitian ini dilakukan dengan tujuan untuk mengetahui pengaruh penambahan tepung mocaf sebagai bahan subtitusi terigu dalam pembuatan bolu kukus terhadap daya pengembangan dan sifat sensoris bolu kukus yang dihasilkan.

\section{METODE PENELITIAN}

\section{Alat dan Bahan}

Peralatan yang digunakan pada penelitian antara lain: timbangan analitik, kompor gas, dandang, baskom, panci pengukus, sendok, talenan, cetakan bolu kukus dan mixer. Adapun bahan yang digunakan adalah: tepung terigu, tepung mocaf, gula pasir, telur, mentega dan vanili.

\section{Pembuatan Bolu Kukus dan Pemberian Perlakuan}

Ditimbang 50 gram tepung, lalu ditambahkan $140 \mathrm{gr}$ gula pasir, $140 \mathrm{gr}$ telur dan 2 gr vanili kemudian dimixer hingga kalis. Kemudian ditambahkan tepung mocaf dan tepung terigu dengan komposisi mocaf berbanding terigu (\%) sebagai berikut: $0: 100$ (Kontrol), 10:90 (P1), 20:80 (P2), 30:70 (P3) serta 40:60 (P4). Setelah itu, ditambahkan mentega $100 \mathrm{gr}$, dan dikukus selama 45 menit. Parameter yang diamati adalah Uji daya pengembangan (Andriani, 2012), serta uji sensoris warna, aroma, tekstur dan rasa.

\section{Uji Sensoris}

Penelitian ini menggunakan uji sensoris dengan panelis berjumlah 25 orang dewasa. Panelis diberikan sampel secara acak dan diminta untuk memberikan penilaian sesuai tingkat kesukaan dengan kriteria sebagai berikut: $1=$ sangat tidak suka

2= tidak suka

$3=$ agak suka

4= suka

$5=$ sangat suka 
Hasil penilaian panelis akan dihitung rata-ratanya. Adapun range tingkat kesukaan panelis adalah sebagai berikut:

Tabel 1. Range Tingkat Kesukaan Panelis

\begin{tabular}{ll}
\hline Skor & Tingkat Kesukaan \\
\hline $1,00-1,49$ & Sangat tidak suka \\
$1,50-2,49$ & Tidak suka \\
$2,50-3,49$ & Agak suka \\
$3,50-4,49$ & Suka \\
$4,50-5,00$ & Sangat suka \\
\hline \multicolumn{2}{l}{ Sumber: (Setyaningsih dkk., 2010) }
\end{tabular}

\section{Rancangan Penelitian dan Analisis Data}

Penelitian ini menggunakan RAL (Rancangan Acak Lengkap) dengan menggunakan 1 faktor perlakuan yaitu subtitusi tepung mocaf pada pengolahan bolu kukus dengan konsentrasi yang berbeda. Tiap perlakuan diulang sebanyak tiga kali.

Dalam uji sensoris, jumlah panelis yang dilibatkan sebanyak 25 orang. Adapun kriteria penilaian panelis adalah sebagai berikut: Hasil yang didapatkan dianalisa menggunakan ANOVA dengan tingkat kepercayaan $5 \%$.

\section{HASIL DAN PEMBAHASAN}

\section{Uji Sensoris Rasa Pada Bolu Kukus}

Hasil penelitian menunjukkan bahwa panelis menyukai rasa bolu kukus yang dibuat dengan subtitusi tepung mocaf (Gambar 1) dengan rata-rata penilaian antara 3,07 (agak suka) hingga 3,57 (suka). Hasil uji sidik ragam (ANOVA) menunjukkan bahwa tidak ada perbedaan nilai yang signifikan antara perlakuan subtitusi tepung mocaf $10 \%, 20 \%, 30 \%$, $40 \%$ serta kontrol (100\% tepung terigu). Hal ini menunjukkan bahwa penambahan tepung mocaf hingga $40 \%$ tidak menurunkan kualitas rasa bolu kukus yang dihasilkan karena terbukti panelis memberikan penilaian rasa yang relatif sama jika dibandingkan dengan kontrol positif yang dibuat dengan 100\% tepung terigu.

Mocaf merupakan produk tepung dari singkong (Manihot esculenta) yang diproses menggunakan prinsip modifikasi sel singkong secara fermentasi, terutama oleh mikroba BAL (Bakteri Asam Laktat). Mikroba yang tumbuh menghasilkan enzim pektinolitik dan selulolitik yang dapat menghancurkan dinding sel singkong sedemikian rupa sehingga terjadi liberasi granulapati. Mikroba tersebut juga menghasilkan enzim-enzim yang menghidrolisis pati menjadi gula dan selanjutnya mengubahnya menjadi asamasam organik, terutama asam laktat. Hal ini akan menyebabkan perubahan karakteristik dari tepung yang dihasilkan berupa naiknya viskositas, kemampuan gelasi, daya rehidrasi, dan kemudahan melarut. Demikian pula, cita rasa mocaf menjadi netral karena menutupi citra rasa singkong sampai $70 \%$ (Subagio dkk., 2008).

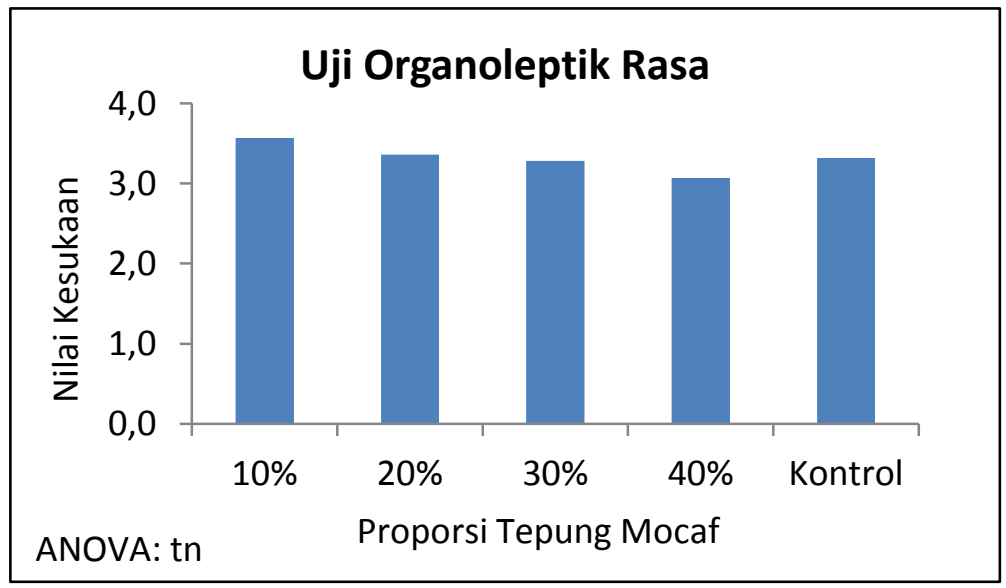

Gambar 1. Nilai Uji Organoleptik Rasa Bolu Kukus dengan Penambahan Tepung Mocaf.

Data yang tersaji dalam grafik adalah nilai rata-rata 25 panelis dengan tiga ulangan. Hasil uji ANOVA pada selang kepercayaan 95\%: F hitung < F tabel (Tidak Berbeda Nyata). 


\section{Uji Organoleptik Aroma Bolu Kukus}

Hasil uji organoleptik aroma bolu kukus dapat dilihat pada Gambar 2. Dari gambar tersebut dapat dilihat bahwa penggunaan tepung mocaf sebagai tepung terigu tidak menurunkan nilai aroma bolu kukus yang dihasilkan. Rata-rata panelis menyatakan "agak suka" dengan bolu kukus yang dihasilkan dengan skor penilaian sebesar 3,35 (P1), 3,31 (P2), 3,25 (P3) dan 3,05 (P4), semua masuk dalam kategori yang sama yaitu "agak suka".

Selanjutnya, hasil uji ANOVA menunjukkan bahwa rata-rata nilai antar perlakuan tidak berbeda nyata. Hal ini berarti bahwa penambahan tepung mocaf hingga $40 \%$ tidak berpengaruh nyata terhadap aroma bolu kukus yang dihasilkan.

Asam laktat yang dihasilkan akibat fermentasi selama proses pembuatan mocaf dapat memberi aroma dan citarasa yang disukai pada mocaf. Citarasa ini dapat menghilangkan aroma apek yang biasanya menjadi ciri khas tepung dan produk olahan dari umbi-umbian (Misgiyarta dkk., 2009).

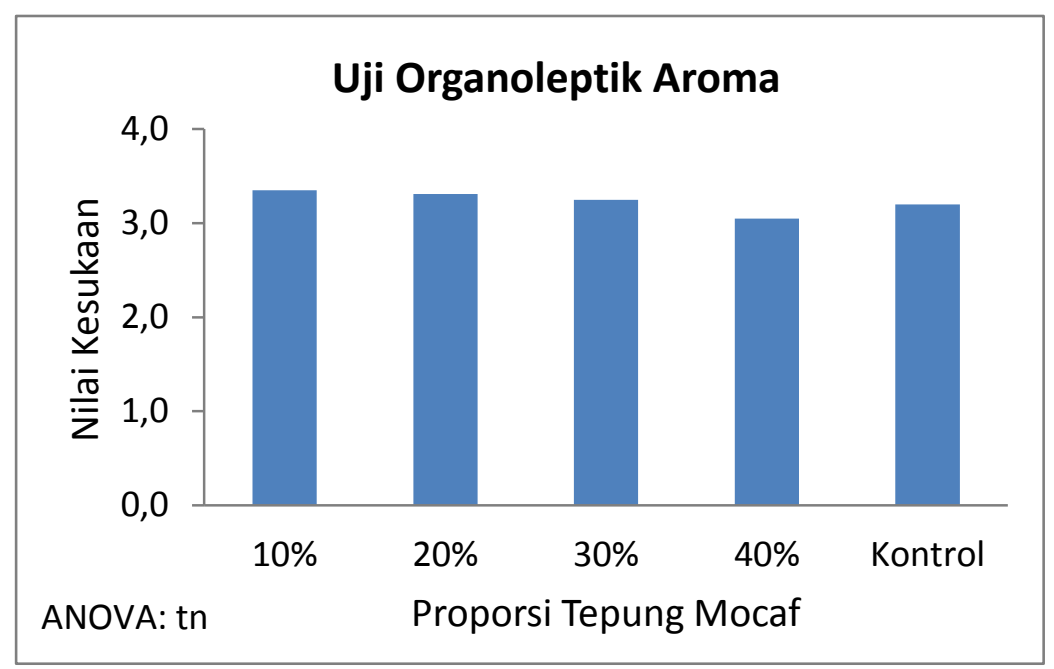

Gambar 2. Nilai Uji Organoleptik Aroma Bolu Kukus dengan Penambahan Tepung Mocaf. Data yang tersaji dalam grafik adalah nilai rata-rata 25 panelis dengan tiga ulangan. Hasil uji ANOVA pada selang kepercayaan 95\%: $\mathrm{F}$ hitung $<\mathrm{F}$ tabel (Tidak Berbeda Nyata).

\section{Uji Organoleptik Warna Bolu Kukus}

Gambar 3 menunjukkan hasil uji organoleptik warna bolu kukus dengan subtitusi tepung mocaf. Dapat dilihat bahwa rata-rata penilaian panelis berkisar antara 3,05 (P3) hingga 3,47 (P1) atau masuk dalam kategori "agak suka". Hasil uji sidik ragam menunjukkan bahwa tidak ada perbedaan nilai yang signifikan antara perlakuan subtitusi tepung mocaf $10 \%$, $20 \%, 30 \%, 40 \%$ serta kontrol positif $(100 \%$ tepung terigu). Hal ini menunjukkan bahwa penambahan tepung mocaf hingga $40 \%$ tidak menurunkan kualitas warna bolu kukus yang dihasilkan karena terbukti memiliki rasa yang relatif sama jika dibandingkan dengan kontrol positif yang dibuat dengan $100 \%$ tepung terigu.
Perendaman dan pencucian yang dilakukan pada pengolahan mocaf menyebabkan sawut terpisah dari kotoran sehingga derajat putihnya meningkat. Selain itu, Selama proses fermentasi terjadi pula penghilangan komponen penimbul warna, seperti pigmen (khususnya pada ketela kuning), dan protein yang dapat menyebabkan warna coklat ketika pemanasan. Dampaknya adalah warna MOCAF yang dihasilkan lebih putih jika dibandingkan dengan warna tepung ubi kayu (Subagio, 2008). Suismono dan Martosuyono (2007) melaporkan bahwa mocaf dari varietas Menado memiliki derajat putih $86,4 \%$, lebih tinggi bila dibanding dengan terigu $(75,0 \%)$. 


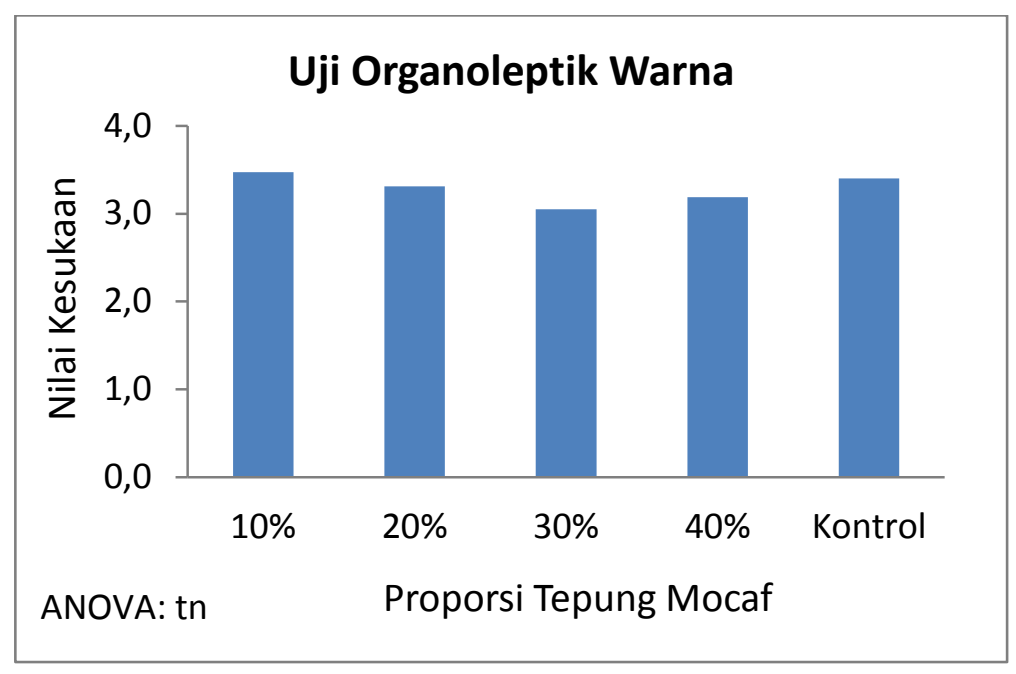

Gambar 3. Nilai Uji Organoleptik Warna Bolu Kukus dengan Penambahan Tepung Mocaf. Data yang tersaji dalam grafik adalah nilai rata-rata 25 panelis dengan tiga ulangan. Hasil uji ANOVA pada selang kepercayaan 95\%: $\mathrm{F}$ hitung $<\mathrm{F}$ tabel (Tidak Berbeda Nyata).

\section{Uji Organoleptik Tekstur Bolu Kukus}

Tekstur adalah penginderaan yang dihubungkan dengan rabaan atau sentuhan. Kadang-kadang tekstur juga dianggap sama penting dengan bau, rasa dan aroma karena mempengaruhi citra makanan. Yang dimaksud dengan tekstur adalah kehalusan suatu irisan saat disentuh dengan jari oleh panelis (De man, 1997). Hasil uji organoleptik tekstur bolu kukus dapat dilihat pada Gambar 4. Hasil penelitian menunjukkan bahwa penggunaan tepung mocaf sebagai tepung terigu tidak menurunkan nilai tekstur bolu kukus yang dihasilkan. Rata-rata panelis menyatakan "agak suka" dengan bolu kukus yang dihasilkan dengan skor penilaian sebesar 3,59 (P1), 3,37 (P2), 3,13 (P3) dan 3,16 (P4). Hasil uji ANOVA menunjukkan bahwa perbedaan nilai antar perlakuan tidak berbeda nyata. Hal ini berarti bahwa penambahan tepung mocaf hingga $40 \%$ tidak berpengaruh nyata terhadap kualitas tekstur bolu kukus yang dihasilkan. Hasil penelitian ini juga menguatkan pernyataan bahwa tepung mocaf adalah bahan yang potensial untuk dijadikan bahan subtitusi terigu karena terbukti bahwa produk yang dihasilkan memiliki tekstur yang relatif sama jika dibandingkan dengan bolu kukus yang berbahan $100 \%$ terigu.

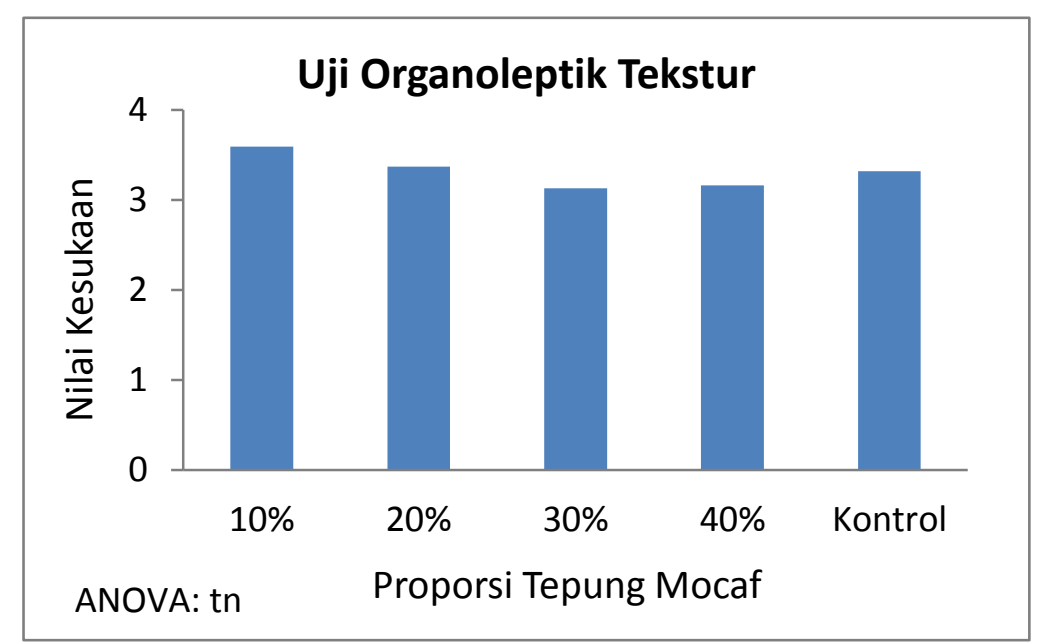

Gambar 4. Nilai Uji Organoleptik Tekstur Bolu Kukus dengan Penambahan Tepung Mocaf. Data yang tersaji dalam grafik adalah nilai rata-rata 25 panelis dengan tiga ulangan. Hasil uji ANOVA pada selang kepercayaan 95\%: F hitung < F tabel (Tidak Berbeda Nyata). 
Fermentasi pada pengolahan mocaf menyebabkan terjadinya perubahan sifat fisikokimia pati ubikayu. Menurut Ramos dkk. (2000), bakteri asam laktat dapat menghasilkan enzim ekstraseluler untuk menghidrolisis pati menjadi dekstrin dan gula sederhana yang selanjutnya dimanfaatkan untuk menghasilkan asam laktat, CO2 dan etanol. Aktivitas enzim amilolitik tersebut menyebabkan granula pati menjadi berlubang-lubang karena terlebih dahulu menyerang bagian yang amorf (amilopektin) sehingga nisbah antara amilosa dan amilopektin meningkat dengan menurunnya proporsi amilopektin (Whistler 1984 dalam Rosida dan Nurasih 2008).

Selain itu, enzim pektin metil esterase dan pektat liase yang dihasilkan bakteri asam laktat juga berperan dalam merusak dinding sel dengan menyerang ikatan pektin glikosida sehingga terjadi disosiasi selulosa dari dinding sel/jaringan pektin. Hal ini menyebabkan tekstur umbi/sawut menjadi lunak dan tepung yang dihasilkan menjadi remah dan lebih mudah larut di dalam air (Yulifianti dkk., 2012).

\section{Uji Pengembangan}

Daya pengembangan bolu kukus merupakan kemampuan bolu kukus mengalami pertambahan ukuran setelah proses pengukusan. Hasil pengukuran daya kembang bolu kukus dengan berbagai perlakuan subtitusi tepung mocaf dapat dilihat pada Gambar 5.

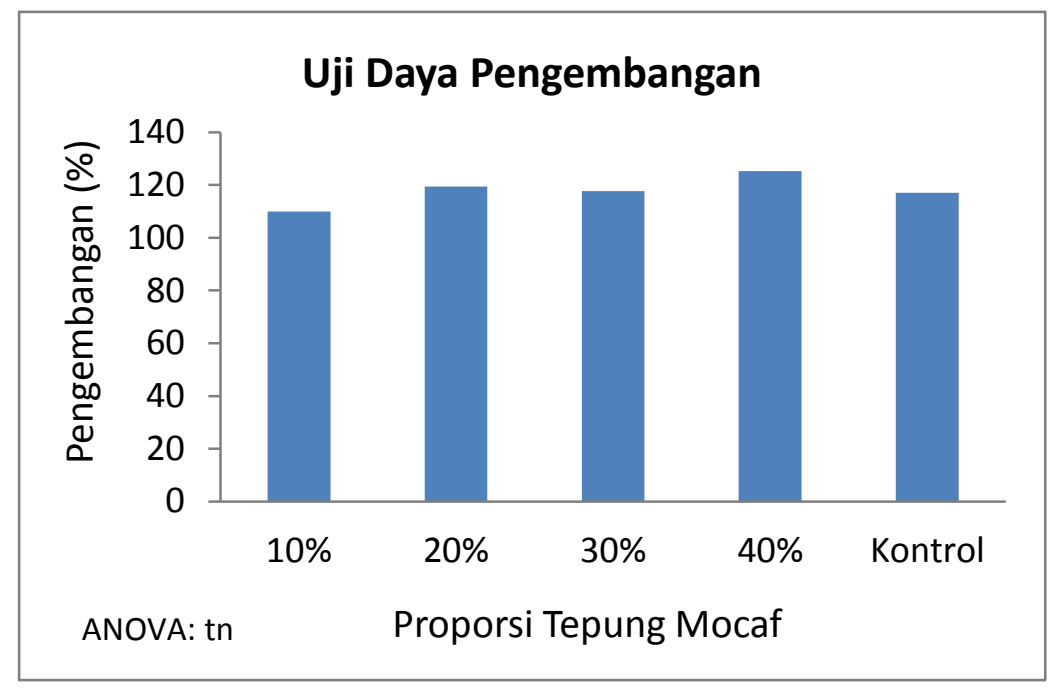

Gambar 5. Nilai Uji Pengembangan Bolu Kukus dengan Penambahan Tepung Mocaf.

Data yang tersaji dalam grafik adalah nilai rata-rata 25 panelis dengan tiga ulangan. Hasil uji ANOVA pada selang kepercayaan 95\%: F hitung < F tabel (Tidak Berbeda Nyata).

Hasil uji daya pengembangan kue bolu kukus dengan penambahan tepung mocaf menunjukkan nilai rata-rata tingkat pengembangan kue bolu kukus berkisar antara $110 \%$ sampai dengan $125 \%$. Pada penelitian ini dapat diketahui bahwa penambahan tepung mocaf dan terigu sebesar 10\%:90\%, 20\%:80\%, 30\%:70\% dan 40\%:60\% masih dapat mengembang cukup baik. Hasil uji ANOVA menunjukkan bahwa tidak ada perbedaan yang nyata diantara nilai rata-rata semua perlakuan. Hal ini menunjukkan bahwa subtitusi tepung mocaf sebesar 10\% hingga $40 \%$ tidak mempengaruhi daya kembang adonan bolu kukus atau relatif sama jika dibandingkan dengan adonan yang berbahan terigu.

Hidrolisis parsial pati pada saat fermentasi menyebabkan derajat polimerisasi amilosa dan amilopektin menjadi lebih kecil (Marcon et al. 2007 dalam Marcon et al. 2009), sehingga viskositas intrinsik pati yang berkaitan dengan berat molekulnya juga turun. Penurunan viskositas intrinsik ini berdampak pada meningkatnya kemampuan mengembang adonan pati asam saat dipanaskan/dipanggang dalam pembuatan roti. Selain itu, permukaan 
granula pati yang berlubang-lubang halus akibat hidrolisis pati tersebut juga meningkatkan kemampuan mengembang adonan roti (Mestress et al. 2000 dalam Marcon et al. 2009). Lubang-lubang tersebut memperkuat ikatan antarbutiran sehingga adonan tidak mudah terputus saat dipanaskan (Duryatmo, 2009)

\section{KESIMPULAN}

Secara keseluruhan, hasil penelitian ini menunjukkan bahwa penggunaan tepung mocaf $(10 \%, 20 \%, 30 \%$ dan $40 \%)$ sebagai bahan subtitusi tepung terigu dalam pembuatan bolu kukus tidak mempengaruhi rasa, aroma, tekstur, warna serta daya kembang bolu kukus yang dihasilkan. Rata-rata panelis memberikan penilaian dengan kriteria "agak suka" terhadap bolu kukus yang dihasilkan dimana tidak berbeda nyata diantara nilai rata-rata hasil penelitian di semua tingkat perlakuan. Hal ini membuktikan bahwa tepung mocaf adalah bahan baku potensial yang dapat dijadikan sebagai bahan alternatif pengganti tepung terigu dalam pembuatan kue. Subtitusi tepung terigu dengan tepung mocaf dapat memberikan manfaat kepada kita berupa pengurangan impor gandum yang merupakan bahan pembuatan tepung terigu.

\section{DAFTAR PUSTAKA}

Badan Pusat Statistik (BPS). 2011. Konsumsi Tepung Terigu. Jakarta: Biro Pusat Statistik.

Central Data Mediatama Indonesia. 2013. Studi Prospek dan Peluang Pasar Industri Tepung Terigu (Gandum) di Indonesia 2013-2017. PT CDMI. Jakarta.

De Man J.M. 1997. Kimia Pangan. Terjemahan Kosasih Padmawinata. Bandung. ITB Bandung.

Diniyah, N., Subagio, A., Sari, R.N.L., Vindy, P.G. dan Rofiah, A.A. 2018. Effect of Fermentation Time and Cassava Varieties on Water Content and the Yield of Starch from Modified Cassava Flour (MOCAF). IJPST 5(2): 71-75.
Duryatmo, S. 2009. Mocaf: Inovasi \& peluang baru. Trubus XL(477):13-17.

Marcon, M.J.A., D.J. Kurtz, J.C. Raguzzoni, I. Delgadillo, M. Maraschin, V. Reginatto and E.R. Amante. 2009. Expansion properties of sour cassava starch (povilho azedo): Variables related to its practical application in bakery. Starch 61: 716-726.

Misgiyarta, Suismono, dan Suyanti. 2009. Tepung Kasava Bimo Kian Prospektif. Warta Penelitian dan Pengembangan Pertanian 31(4): 1-4.

Ramos, C.H., Hoffman,T., Marino, M., Nedjari, H., Presecan-Siedel, E., Dreesen, O., Glaser, P., and D. Jahn. 2000. Fermentative metabolism of Bacillus subtilis: Physiology and regulation of gene expression. $J$ of Bacteriol 182(11): 3072-3080.

Rosida dan A.S. Nurasih 2008. Kajian konsentrasi bakteri asam laktat dan lama fermentasi pada pembuatan tepung pati singkong asam. Agritech 28(3): 97-101.

Ruriani, E., Nafi, A., Yulianti,L.D. dan Subagio, S. 2013. Identifikasi Potensi MOCAF (Modified Cassava Flour) sebagai Bahan Pensubstitusi Teknis Terigu pada Industri Kecil dan Menengah di Jawa Timur. PANGAN 22(3): $229-240$.

Setyaningsih, D., Apriyantono, A. dan Sari, M.P. 2010. Analisa Sensori Industri Pangan dan Agro. IPB Press, Bogor.

Subagio, A. 2008. Modified Cassava Flour (MOCAL): Sebuah Masa Depan Ketahanan Pangan Nasional Berbasis Potensi Lokal. Pangan 50 (12): 92103.

Subagio, A., Windrati, W.S., Witono, Y. dan Fahmi, F. 2008. Rusnas Diversifikasi Pangan Pokok. Prosedur Operasi Standar (POS) Produk Mocal Berbasis Klaster. Jember: Fakultas Teknologi Pertanian-SEAFAST Center IPB.

Suismono Dan P. Martosuyono. 2007. Perbaikan Mutu Tepung Ubikayu Melalui Modifikasi Secara Biologi. hlm. 511-520. Dalam D. Harnowo, A.A. Rahmianna, Suharsono, M.M. Adie, F. Rozi, Subandi. A.K. Makarim, A. Winarto, T. Fitriyanto, dan B.S. Kuncoro (ed). Peningkatan Produksi 
Kacang-kacangan dan Umbi-umbian Mendukung Kemandirian Pangan. Puslitbang Tanaman Pangan. Bogor.

Yulifianti, Rahmi, Erliana Ginting, dan Joko Susiloutomo. 2012. Tepung Kasava Modifikasi sebagai Bahan Substitusi Terigu Mendukung Diversifikasi Pangan. Buletin Palawija. 